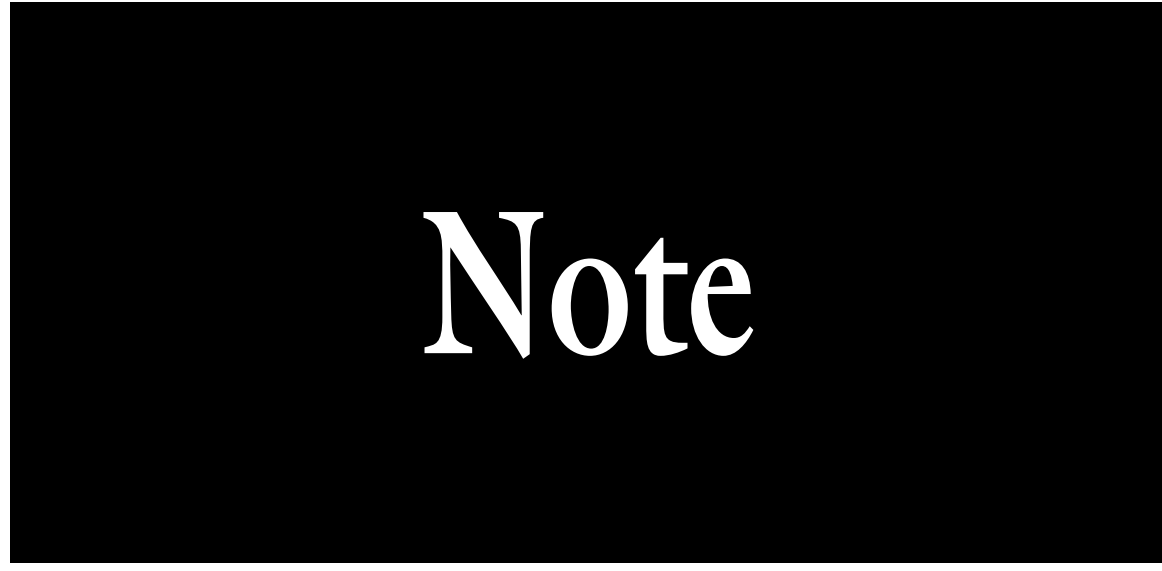

\title{
CropMAP: A Location-specific Resource for Crops in the United States
}

\author{
Jules Janick and Anna Whipkey
}

AdDITIONAL INDEX wORDs. agricultural census, crop statistics, new crops, U.S. counties

$\overline{\text { Summary. A location-specific resource about crops called CropMAP was developed }}$ as part of a web-based project of the Purdue University Center for New Crops and Plant Products. The prototype was developed from the 1992 agricultural census for the state of Indiana. Subsequently, the concept was extended to all states using the agricultural census data for 1997 and was recently updated by adding data from the 2007 census. CropMAP has been available on the NewCROP website but the resource has not been generally publicized. The objective of this communication is to make CropMAP better known since it has proven to be a useful and unique resource.

\section{NEWCROP}

The New Crops Resource Online Program (NewCROP) is a webbased resource project of the Purdue University Center for New Crops and Plant Products that was initiated in 1994 and became operational in 1995 (Simon et al., 1996). Its original goal was to make information on new crops readily available on the web, but it was expanded to all crops. The site can be found easily with a search engine by using the keyword "newcrop" [Fig. 1 (Purdue University Center for New Crops and Plant Products, 2013)]. Throughout the years, the website has received considerable activity (Fig. 2).

The NewCROP website consists of a number of resources. CropINDEX is a searchable database emphasizing useful information on all crops listed alphabetically by common name and

Department of Horticulture and Landscape Architecture, Purdue University, West Lafayette, IN 47907 2010

We thank Alexandra Wittenberg for updating census information species (2845 entries) and includes information from six New Crop Conferences held by the Purdue University Center for New Crops, many of which were cosponsored by the American Association for Industrial Crops and the U.S. Department of Agriculture (USDA) (Janick, 1996 , 1999; Janick and Simon, 1990, 1993; Janick and Whipkey, 2002, 2007). CropREFERENCE lists books and manuals. CropEXPERT is a directory of new crop researchers. IMPORTEXPORT provides quarantine information and phytosanitary permits for a number of countries. Famine Foods is a database developed by Bob Freedman (Tucson, AZ) on plants that are not normally considered as crops but consumed at the time of famine. There are links to websites, external databases, and libraries. CurrentPROJECTS lists classes, presentations, papers, websites, cultivar releases, and working documents produced by Jules Janick (Director) and Anna Whipkey (Web developer) of the Purdue Center for New Crops and Plant Products. Finally, CropMAP (Janick et al., 1996) was developed as a nationwide (United States) site-specific crop information system (see below).

CropMAP. Information on crop statistics (crop, number of farms, crop area, and yield) is available in the agricultural census that is collected every five years. Data are available from each county equivalent of the 50 states (3033 total) and is published by the USDA in five-year intervals. Information from the census is also online but data from different years are not collated and are awkward to access. CropMAP, a sitespecific retrieval system that is meant to be user friendly, is based on three concepts: 1) the development of an interactive map of each county and state of the United States; 2) the incorporation of county crop statistics from the U.S. agricultural census of 1997 and 2007 (2002 data are also presented for Indiana); and 3 ) the addition of county information such as links to the extension offices, geopolitical maps, Level III ecoregions (U.S. Environmental Protection Agency, 1999), and hardiness zones (USDA, 1990). CropSELECT provides general advice on suitable and unsuitable crops for Indiana, but this has not been expanded to most states.

Systems environment. The NewCROP server runs in a VMware Virtual Environment. HyperText markup language is written using editing programs such as Dreamweaver (Adobe Systems, San Jose, CA), and the searchable databases are created with FileMaker Pro (FlieMaker, Santa Clara, CA). Construction of NewCROP server began on Oct. 1994 and the system went online by 15 Mar. 1995 (Purdue University Center for New Crops and Plant Products, 2013).

Navigation. CropMAP presents the viewer with a map of the United States with its 50 states plus an alphabetical list. The flow chart for CropMAP is diagrammed in Fig. 3. Clicking on any state (image or list) brings up the state with its county images displayed in contrasting colors as well as a list in alphabetical order. Various types of state information are presented including population data, state census of agriculture data, geopolitical map, Level III ecoregions, 


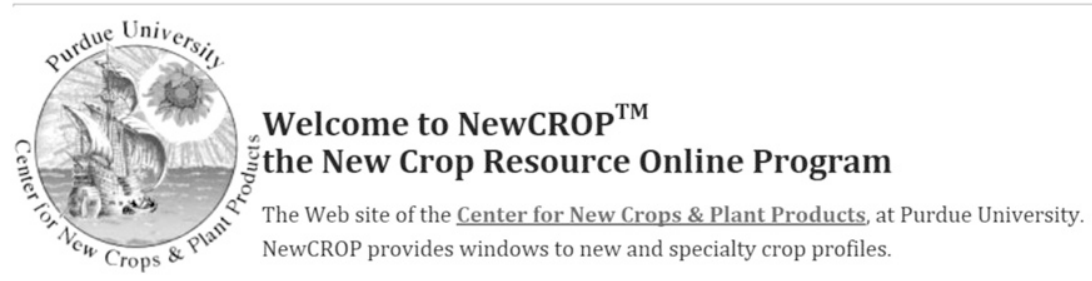

Help Strategies for using NewCROP
CropINDEX A list of scientific and common names of crops for information access
CropSEARCH Google it!
CropMAP A nation-wide (US) location-specific crop information system
Current Projects Classes, presentations, websites

CropREFERENCE Books and manuals on crops

CropEXPERT Directory of new crop resource personnel

NewCropEVENTS Conferences, events and upcoming symposia

IMPORT_EXPORT Plant quarantine information and phytosanitation permits for all countries.

Famine Foods A list of unconventional food sources

NewCrop LINKS Connections to related web sites, external data-bases, and libraries Australian New Crops Project

Fig. 1. NewCROP home page.

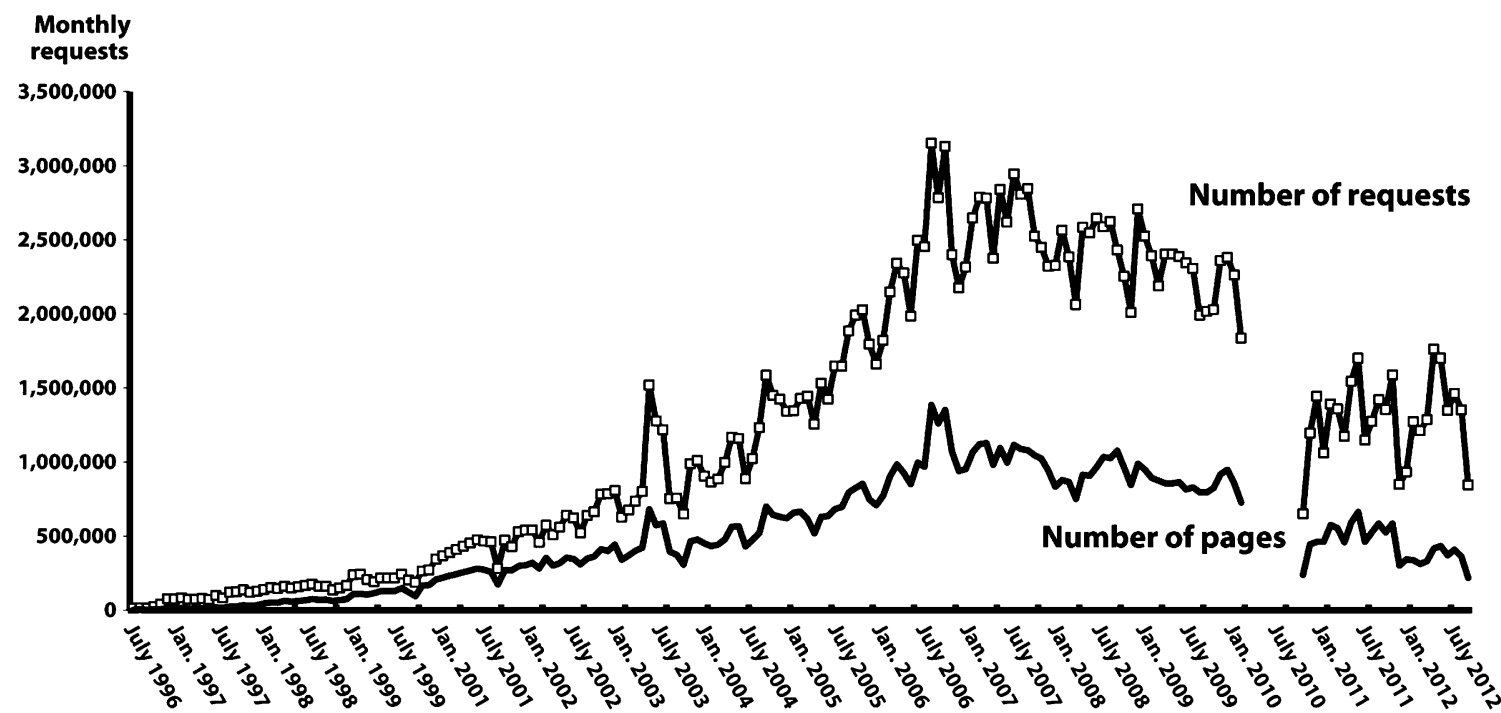

Fig. 2. NewCROP web server statistics, July 1996 to Sept. 2012.

and hardiness zones. County data can be similarly accessed and include a county map, crop statistics, and links to the extension offices. The Indiana map also contains agricultural markets.
FUTURE DEVELOPMENT. CropMAP is a dynamic database and its continuing improvement will depend on further inputs and efforts to make the information current. Thus, data from the 2012 agricultural census need to be added when available. A plan to establish state coordinators has been initiated but needs to be updated and completed. The map of hardiness zones requires updating with the new USDA maps recently created (USDA, 2012). 


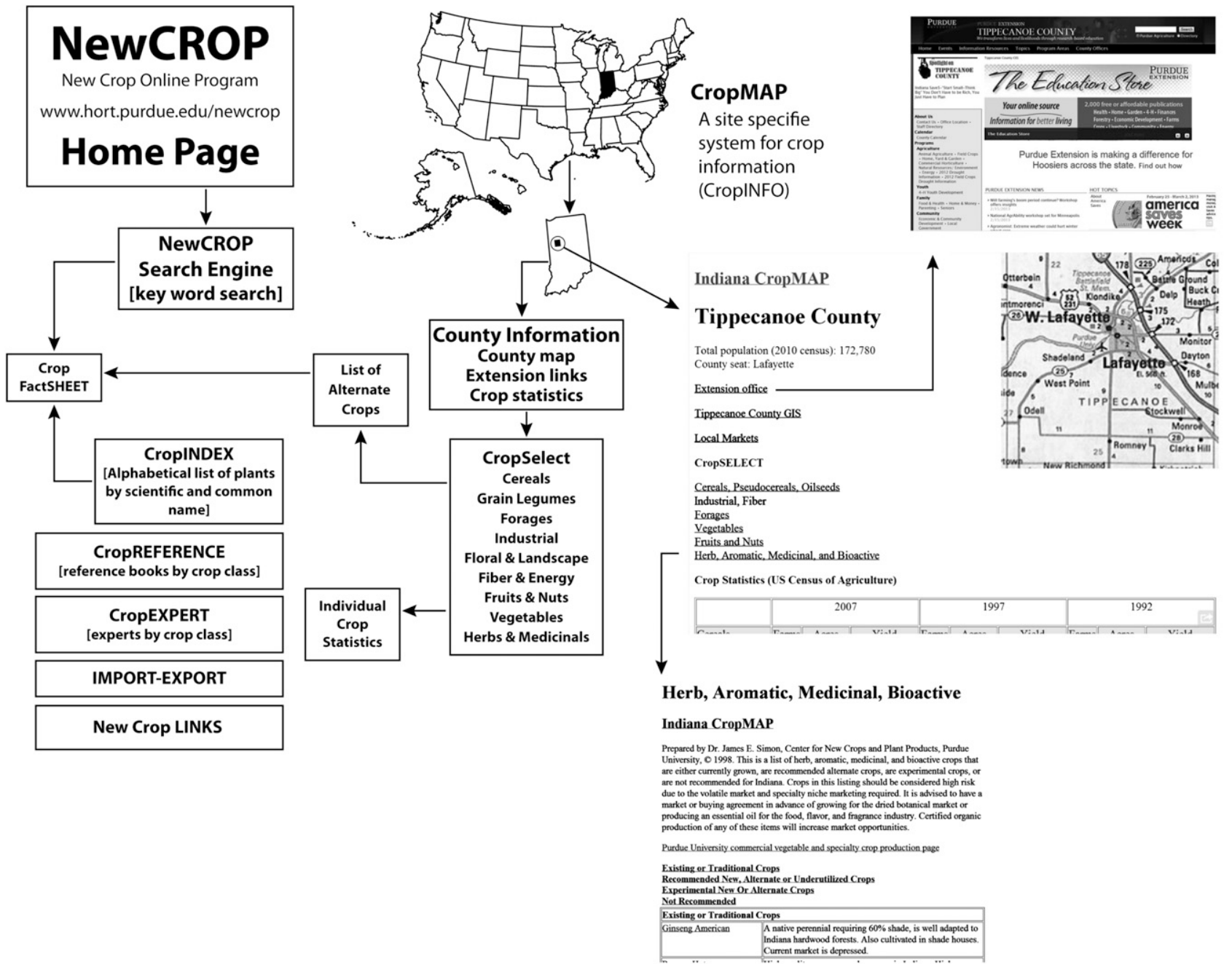

Fig. 3. Flowchart for CropMAP.

The concept of CropSELECT should be added on a state level to give additional information on suitable traditional and alternate crops for each state. Marketing information for each county could be added as listed for Indiana.

\section{Literature cited}

Janick, J. (ed.). 1996. Progress in new crops. ASHS Press, Alexandria, VA.

Janick, J. (ed.). 1999. Perspectives on new crops and new uses. ASHS Press, Alexandria, VA.

Janick, J., J.E. Simon, and A. Whipkey. 1996. A site-specific retrieval system for crop information, p. 166-168. In: J. Janick (ed.). Perspectives on new crops and new uses. ASHS Press, Alexandria, VA.

Janick, J. and J.E. Simon. (eds.). 1990. Advances in new crops. Timber Press Portland, OR.
Janick, J. and J.E. Simon (eds.). 1993. New crops. Wiley, New York, NY.

Janick, J. and A. Whipkey (eds.). 2002. Trends in new crops and new uses. ASHS Press, Alexandria, VA.

Janick, J. and A. Whipkey (eds.). 2007. Issues in new crops. ASHS Publications, Alexandria, VA.

Purdue University Center for New Crops and Plant Products. 2013. Welcome to NewCROP ${ }^{\mathrm{TM}}$ the new crop resource online program. 18 Feb. 2013. <http:// www.hort.purdue.edu/newcrop/>.

Simon, J.E., J. Janick, and A. Hetzroni. 1996. The NewCROP electronic network, p. 142-147. In: J. Janick (ed.). Progress in new crops. ASHS Press, Alexandria, VA.

U.S. Department of Agriculture. 1990. USDA plant hardiness zone map. U.S. Dept. Agr. Misc. Publ. 1475.
U.S. Department of Agriculture. 1997. Census of agriculture. 18 Feb. 2013. <http: //www.agcensus.usda.gov/Publications/ 1997/index.php>.

U.S. Department of Agriculture. 2002. Census of agriculture. 18 Feb. 2013. <http: //www.agcensus.usda.gov/Publications/ 2002/index.php>

U.S. Department of Agriculture. 2007. Census of agriculture. 18 Feb. 2013. <http: //www.agcensus.usda.gov/Publications/ $2007 /$ index.php $>$.

U.S. Department of Agriculture. 2012. USDA plant hardiness zone map. $18 \mathrm{Feb}$. 2013. <http://planthardiness.ars.usda. gov/PHZMWeb/>.

U.S. Environmental Protection Agency. 1999. Level III and IV Ecoregions of the continental United States. 19 Feb. 2013. <http://www.epa.gov/wed/pages/ ecoregions/level_iii_iv.htm>. 